4-30-2018

\title{
Market Imperfections, Macroeconomic Conditions, and Capital Structure Dynamics: A Cross-Country Study
}

Moonsoo Kang

Wei Wang

Cleveland State University, w.wang24@csuohio.edu

Ying Xiao

Follow this and additional works at: https://engagedscholarship.csuohio.edu/bus_facpub

Part of the Finance and Financial Management Commons, and the Macroeconomics Commons How does access to this work benefit you? Let us know!

Publisher's Statement

"This is an Accepted Manuscript of an article published by Taylor \& Francis in Emerging Markets Finance and Trade on April 30th, 2018, available online: http://www.tandfonline.com/10.1080/ 1540496X.2017.1326380."

\section{Recommended Citation}

Kang, Moonsoo; Wang, Wei; and Xiao, Ying, "Market Imperfections, Macroeconomic Conditions, and Capital Structure Dynamics: A Cross-Country Study" (2018). Business Faculty Publications. 283.

https://engagedscholarship.csuohio.edu/bus_facpub/283

This Article is brought to you for free and open access by the Monte Ahuja College of Business at EngagedScholarship@CSU. It has been accepted for inclusion in Business Faculty Publications by an authorized administrator of EngagedScholarship@CSU. For more information, please contact library.es@csuohio.edu. 


\title{
Market Imperfections, Macroeconomic Conditions, and Capital Structure Dynamics: A Cross-Country Study
}

\author{
Moonsoo Kang Wei Wang and Ying Xiao
}

\begin{abstract}
This article investigates how "systematic" adjustment costs proxied by market imperfections, and macroeconomic conditions affect capital structure dynamics in a cross-country setting. We document substantial variations in firms' capital structure adjustments across countries and, particularly, over time. Consistent with adjustment costs impeding firms from rebalancing their capital structures, worse market imperfections are associated with slower speeds of adjustment (SOA) and larger leverage deviations. Intertemporally, capital structure adjustment is procyclical, with SOA increasing by 0.9 percentage point for a one-percentage-point increase in GDP growth rate. The procyclicality is attributable to good macroeconomic conditions mitigating market imperfections through channels of 1 ) facilitating free-ride restructuring and 2) uncertainty alleviation. Our investigation features a bootstrapping-based estimation method that addresses the mechanical mean reversion of leverage ratio.
\end{abstract}

KEYWORDS: adjustment costs, capital structure, macroeconomic conditions, market imperfections, mechanical mean reversion, procyclicality, speed of adjustment (SOA)

Firms could deviate from their optimal capital structures and any rebalancing toward the optimum is not only sluggish, ${ }^{1}$ but also heterogeneous across firms. ${ }^{2}$ This is interpreted as consistent with adjustment costs impeding firms from pursuing their capital structure targets (e.g., Fischer, Heinkel, and Zechner 1989; Strebulaev 2007). Firms rebalance their capital structures, if and only if the adjustment benefits exceed the adjustment costs, and thus greater adjustment costs lead to slower speeds of adjustment (SOA).

Adjustment costs stem from market imperfections, which vary across countries as well as over time. Among others, Jappelli and Pagano (1989) attributed the cross-country variations of excess consumptionto-income sensitivity to different degrees of capital market imperfections; Choe, Masulis, and Nanda (1993) showed that firms sell equity more frequently in expansionary periods when they face lower adverse selection costs; Eisfeldt (2004) held that the standard business cycle fundamental, productivity, determines the countercyclical adverse selection costs in the capital markets. As such, we hypothesize that firms exhibit slower capital structure adjustments in countries with worse market imperfections and when the economy is in the downturn, because the adjustment costs faced by all firms as a whole, or the "systematic" adjustment costs, are greater.

We test this hypothesis in a large cross-country sample spanning 40 major economies during 1995-2010, which features a vast diversity in institutional and developmental features as well as dramatic ups and downs in macroeconomic conditions. Our data enable us to conduct the first investigation that reveals not only across-country, but also intertemporal variation in capital structure dynamics. We find that capital structure SOA varies substantially both across countries as well as over time. The lowest countrylevel SOA is nearly zero in Japan, where the economy has been stagnant during our sample period, but firms in Norway exhibit a SOA of 0.24 , corresponding to a half-life of only 2.6 years. Across all countries, 
the annual SOA is the fastest around 2006 at a level of 0.18 , and reaches its low in 2008, being around 0.05 for book leverage and around -0.05 for market leverage - market leverage deviation from the target deteriorates.

Country characteristics that proxy for market imperfections correlate with the capital structure SOA. In particular, a legal and institutional environment that ameliorates market frictions facilitates faster adjustments. Better transparency and information dissemination are conducive to capital structure adjustments. Market concentration is also associated with faster adjustments, potentially resulting from the economy of scale in transaction costs. However, market imperfections seem to be inadequate to explain the cross-sectional differences in capital structure dynamics. The stark contrast between Norway and Japan, both with an above-average institutional environment, showcases the importance to consider the effect of macroeconomic conditions on capital structure dynamics.

Intertemporally, capital structure adjustments exhibit a strong procyclical pattern. The GDP growth rate is positively associated with SOA and the frequency of firms' issuance/repurchase activities. The association is economically significant: a one-percentage-point improvement in the GDP growth rate leads to an SOA that is faster by a 0.9 percentage point, which is large given the diversity in economic growth across countries and over time. Most of the explanatory power of GDP growth dissipates when it is orthogonalized against the growth in capital formation and the stock market volatility index. These two additional measures of economic conditions load in the multivariate regression with a positive and negative sign, respectively. This suggests that economic booms lower firms' capital structure adjustment costs via at least two channels: 1) free-ride restructuring, i.e., firms' vibrant capital expenditures in good times incur capital market visits of which capital structure adjustments take a free ride and 2) uncertainty alleviation, i.e., good times witness reduced uncertainty and more transparency.

This article employs the Iliev and Welch (2010) bootstrapping-based approach to estimate the capital structure adjustment speeds. This approach reconciles existing estimators of the partial adjustment model and justifies the use of the OLS estimator for finding the SOA for a cross section of firms in a year or a country-year when the well-received system GMM estimator (e.g., Flannery and Hankins 2013; Lemmon, Roberts, and Zender 2008) requires panel data. Additionally, the approach addresses the issue of mechanical mean reversion of leverage ratio that causes upwardly biased SOA estimates (Chang and Dasgupta 2009; Chen and Zhao 2007), by comparing the estimate in the real data against those in bootstrapped placebo samples where leverage evolves with randomly chosen equity and debt financing. The raw estimate in the real data and the placebo estimates are both subject to similar estimation biases, including the spurious adjustment due to mechanical mean reversion, but differ from one another in the presence/ absence of managerial interventions. The difference between the two estimates hence depicts the effect of deliberate capital structure adjustments, net of estimation biases.

Ceteris paribus, faster capital structure adjustments would lead to smaller deviation from target leverage. Alternatively, the presence of adjustment costs defines an inactivity band within which the net benefit of adjustments is not big enough to offset the adjustment costs. The band width increases with the adjustment costs, giving rise to a greater deviation from the target leverage. We test this auxiliary hypothesis by running a regression of average leverage deviation in a country-year on measures of market imperfections and macroeconomic conditions, and find that a positive association between leverage deviation and market imperfections and a positive one between leverage deviation and macroeconomic conditions. This finding echoes Myers (1984)'s view that adjustment costs give rise to capital structure variation. The discussion of this investigation and results are in the online Supplementary Material, Section C.

\section{Related Literature}

This article mainly relates to two strands of empirical capital structure literature. The first endeavors to find out the relation between capital structure adjustments and their costs at the firm level. Representative works include Jalivand and Harris (1984), Elsas and Florysiak (2011), Dudley (2012), Faulkender et al. (2012), and Lockhart (2014). They typically instrument adjustment costs with certain firm characteristics and report a negative relation between adjustment costs and SOA. Our use of country characteristics and 
macroeconomic conditions as proxies of "systematic" adjustment costs confers an advantage because they are less likely to be subject to the endogeneity problem compared to firm characteristics. ${ }^{3}$

The other strand of literature attempts to answer the question if capital structure theories apply to firms in countries other than the United States. A series of articles, including Rajan and Zingales (1995), Booth et al. (2001), De Jong, Kabir, and Nguyen (2008), and Fan, Titman, and Twite (2012), investigate the determinants of capital structure in the international setting. Drobetz, Pensa, and Wanzenried (2006) estimated the capital structure SOA in European countries and show that financial constraints matter. In a similar effort, Driffield and Pal (2007) estimated the capital structure SOA in European and East Asian countries and document cross-country variations.

This article furthers their efforts and look into what determine capital structure adjustments in an international setting. Öztekin and Flannery (2012) represented the first endeavor in this front and find that an array of legal and institutional features, which are essentially time invariant, help explain cross-country variation in SOA. This article differs mainly in three respects. One, we use a panel of country characteristics that allows us to expose the intertemporal variations in capital structure adjustments, while Öztekin and Flannery (2012), restricted by data, conduct largely cross-sectional analyses. Two, we reveal that average leverage deviation from target is positively related to market imperfections. This represents the more direct response to Myers' insight that adjustment costs give rise to capital structure variations. Three, our bootstrapping-based estimator of SOA addresses the mechanical mean reversion issue of capital structure. Our findings hence complement and extend those of Öztekin and Flannery (2012).

As it comes to the time-varying nature of capital structure behavior, Hackbarth, Miao, and Morellec (2006) theoretically analyzed the impact of macroeconomic conditions on dynamic capital structure choice, and predict that underlevered firms should adjust their capital structures more often during economic expansions. Empirically, Drobetz and Wanzenried (2006) demonstrated that SOA depends on the state of the business cycle in a small Swiss sample, and Cook and Tang (2010) found that U.S. firms exhibit faster SOAs in booms than in recessions. Different from theirs, our investigation uses a cross-country sample that includes all major economics, allowing for country-level market imperfections to affect capital structure dynamics.

Our bootstrapping-based estimation strategy builds on the discussion of the mechanical mean reversion of leverage ratio. Chen and Zhao (2007) pointed out that the leverage ratio is by definition mean reverting as long as a firm's assets grow. Chang and Dasgupta (2009) showed that mean reversion arises even when firms follow a random financing strategy. Because the partial adjustment model takes the coefficient of lagged leverage as one minus SOA, it cannot distinguish readjustment from mechanical mean reversion. To address this issue, Iliev and Welch (2010) proposed a reasonable placebo data generating process for leverage ratio assuming random debt and equity financing to expose the spurious adjustment, and show that SOA estimates based on different estimators can be reconciled after the spurious adjustment is taken away. Mukherjee and Wang (2013) used this bootstrapping-based estimator and find leverage SOA increases with initial leverage deviation. We borrow their data generating process and apply it to our international data.

\section{Data and Method}

In this section, we describe in details our sample, particularly the proxies of market imperfections, present the capital structure adjustment model, and elaborate the bootstrapping-based estimation procedure.

\section{Data}

We obtain the firm-level variables from Compustat Global Vantage, and the country-level variables from various sources, mainly the World Development Indicators (WDI) database and Doing Business database of the World Bank. Other sources include SDC Platinum, Transparency International, and a few prior articles like La Porta et al. (1997, 1998), Beck and Demirgüç-Kunt (2009), and Fan, Titman, and Twite (2012). We require that each firm in our sample have at least two consecutive years of observations, and a 
country included must have nonmissing country variables and at least 500 firm-year observations during the sample period of $1995-2010 .{ }^{4}$ Our country sample spans developed OECD members such as the United States and Japan, largest emerging markets such as Brazil, China, India and Russia, and some smaller developing economies like Pakistan and Philippines as well. Combined they contributed over $90 \%$ of the world GDP in recent years. Firms with assets less than 10 million U.S. dollars in 2005 dollar are excluded. Then we keep only country-years with at least 25 firms because of the need to estimate an SOA for each country-year. Our final sample has 590 country-years and 219,856 firm-year observations during the 1995-2010 period for 30,489 nonfinancial, nonutility firms in 40 countries. The list of the countries is in Table S1 of the online Supplemental Material. The United States provides about $30 \%$ of all the firm-year observations; other countries/areas with over 10,000 firm-year observations are Japan, the United Kingdom and Canada; while several countries such as Argentina, Austria, and Ireland have fewer than 1,000 observations.

\section{Firm-Level Variables}

We measure capital structure by both the book and market debt-to-capital ratio. The former is defined as the total debt divided by the sum of debt and book equity, and the latter as the total debt divided by the sum of debt and market value of equity. Table 1 displays the average leverage ratios in the full sample and in each individual country. The sample-wide averages for book and market debt-to-capital ratios are 0.33 and 0.29 , respectively. The leverage ratios exhibit considerable variations across countries: A few of them like Portugal, Korea, and Indonesia have average ratios in excess of 0.45 , while countries like Australia, UK, and South Africa witness book leverage ratios of below 0.30 and market leverage ratios below 0.25 . These discrepancies might reflect differences in law, institutions and taxation across countries as documented in prior literature (e.g., La Porta et al. 1998) as well as different firm characteristics in those countries (e.g., Rajan and Zingales 1995).

Following the literature, the target leverage is modeled as a function of a vector of firm and industry characteristics, including the log of assets, market-to-book ratio, profitability, asset tangibility, depreciation, research and development intensity, a dummy indicating the availability of the R\&D information, and the median leverage in the 2-digit industry. The assets of a firm are denominated in the year 2005 U.S. dollar based on the exchange rate between the firm's accounting currency and the U.S. dollar in the year, and the U.S. consumer price index (CPI) in that year compared to year 2005. Market-to-book ratio is defined as (book value assets - book value of common equity + market value of common equity) divided by book value assets. Profitability, tangibility, depreciation and R\&D intensity are defined as operating income before depreciation, net property, plant and equipment, depreciation and amortization, and $R \& D$ expenses, respectively, as a ratio of the total assets. Ratios are winsorized at the first and 99 th percentiles to mitigate the influence of outliers. In addition, country and year dummies are included to control for the effect of market imperfections and macroeconomic conditions on the level of capital structure.

\section{Country-Level Variables}

Market imperfection factors. We are interested in country characteristics that could affect adjustment costs of capital structure. Stemming from market imperfections (e.g., DeGennaro 2005), the adjustment costs under examination encompass all costs, direct and indirect, incurred by equity issuance/repurchase or debt issuance/retirement aimed at restoring optimal capital structure. Well-known costs include fees that go to the regulatory agency, the investment banks, the attorney, transaction costs for equity repurchase and renegotiation costs for equity or debt repurchase. After analyzing the sources of these costs and the availability of data, we use 13 country-level variables that proxy for factors that affect adjustment costs in a systematic way. ${ }^{5}$ Many of these variables are intercorrelated with each other, and hence we group and combine them into five factors using principal component analysis (PCA). These factors are, respectively, Institutional environment (based on common law, market-based financial system, corruption perception index, creditor legal rights and shareholder right protection), Corporate transparency (based on 
Accounting standards and depth of credit information), Financial market development (based on size of equity market and amount of private credits), Market concentration (based on equity underwriter concentration and bank concentration), and Infrastructure (based on numbers of telephone lines and internet users per 100 people). The definition of the 13 original variables is in the Appendix. The description of the five factors is available in the online Supplemental Material, Section A.1.

Macroeconomic conditions. Macroeconomic conditions could influence capital structure adjustments. When an economy is growing healthily, vibrant capital spending by the private sector induces frequent external financing activities. These activities provide firms good opportunities to readjust their capital structures, if not already optimal. Put it another way, capital structure adjustments can free ride external financing activities due to investment needs and enjoy lower costs of adjustments. We call this idea the "free-ride restructuring" hypothesis. Similar arguments are made by Faulkender et al. (2012) at the firm level, which shows that firms with large cash flows exhibit fast capital structure adjustments.

In addition, economic expansions (contractions) accompany dwindling (inflated) perceived uncertainty about the future, which in turn decreases (increases) market frictions (e.g., Bachmann and Moscarini 2011; Bloom 2009; Choe, Masulis, and Nanda 1993; Eisfeldt 2004). We call this effect the "uncertainty alleviation" hypothesis. Obviously, this effect works in the same direction as the "freeride restructuring" effect.

We use the GDP growth rate to measure macroeconomic conditions in general and expect it to be positively related to leverage SOA and negatively to initial leverage deviations. To test the "free-ride restructuring" and "uncertainty alleviation" hypotheses, we adopt the growth rate of capital formation and the CBOE market volatility index (VIX) to measure the intensity of capital expenditures and the perceived uncertainty, respectively. ${ }^{6}$

Control variables. We control for adjustment benefits. The tradeoff theory rests on weighing mainly interest tax savings against bankruptcy costs. Holding bankruptcy costs fixed, higher tax benefits would create a greater incentive for underlevered firms to use more debt; holding tax benefits fixed, larger bankruptcy costs encourage overlevered firms to lower the leverage. Thus, we construct the two factors, using principal component analysis, to control for Tax advantage of debt and Bankruptcy costs. The former is based on the highest statutory corporate income tax rate and the tax deductibility code in a country, and the latter on time to resolve insolvency and cost of debt recovery. The definition of the original variables are in the Appendix, and the description of the two factors is available in the online Supplemental Material, Section A.2.

Statistic summary. Table 1 presents the statistic summary of the 13 original country-level variables, the five market imperfection factors, and the two factors controlling for adjustment benefits. Country characteristics and macroeconomic conditions exhibit great variations. Just a few examples: GDP growth rate ranges from $-13.1 \%$ to $14.5 \%$; stock market capitalization ranges from three percent of GDP to 10.88 times GDP. There were no internet users in some countries in 1990s, but in 2010 a few countries boast internet coverage of over 90 percent. Large cross-sectional as well as intertemporal variations in country-level variables enable valid inferences about the issue of our interest, i.e., the relation between systematic adjustment costs and capital structure adjustments.

To highlight intertemporal variations in country-level variables, we display the five market imperfection factors and macroeconomic conditions during our sample period in Figure 1. Institutional environment is stable, while all other imperfection factors change substantially over time. Corporate transparency and infrastructure rise monotonically over time, financial market development is procyclical and market concentration exhibition a countercyclical pattern. The average GDP growth rate dips in 1998 following the Asian financial crisis, and again in 2001 and 2002 subsequent to the dot- 
Table 1. Country characteristics.

\begin{tabular}{|c|c|c|c|c|c|}
\hline Variable & Mean & Median & Std Dev & Min & Max \\
\hline \multicolumn{6}{|l|}{ Original variables } \\
\hline Common law & 0.35 & 0.00 & 0.48 & 0 & 1 \\
\hline Market-based financial system & 0.50 & 0.50 & 0.50 & 0 & 1 \\
\hline Corruption perception index $(0-10)$ & 6.30 & 6.95 & 2.43 & 1.7 & 10 \\
\hline Creditor legal rights $(0-10)$ & 6.42 & 7.00 & 2.29 & 3 & 10 \\
\hline Shareholder right protection $(0-10)$ & 6.16 & 5.85 & 1.68 & 3 & 9.7 \\
\hline Accounting standards & 0.25 & 0.04 & 0.37 & 0 & 1 \\
\hline Depth of credit information (0-6) & 4.74 & 5.00 & 1.10 & 0 & 6 \\
\hline Size of equity market & 0.89 & 0.65 & 0.94 & 0.06 & 10.88 \\
\hline Amount of private credits & 0.96 & 0.97 & 0.50 & 0.10 & 2.32 \\
\hline Equity underwriter concentration & 0.13 & 0.10 & 0.12 & 0.01 & 1 \\
\hline Bank concentration & 0.66 & 0.65 & 0.21 & 0.12 & 1 \\
\hline Telephone lines (per 100 people) & 38.61 & 44.02 & 19.76 & 1.72 & 74.46 \\
\hline Internet users (per 100 people) & 33.96 & 28.18 & 27.75 & 0.00 & 93.28 \\
\hline Corporate income tax rate & 0.31 & 0.32 & 0.07 & 0.13 & 0.57 \\
\hline Interest tax deductibility & 1.39 & 2.00 & 0.74 & 0 & 2 \\
\hline Time to resolve insolvency (years) & 2.33 & 1.80 & 2.00 & 0.4 & 10 \\
\hline Cost of debt recovery $(\%)$ & 23.25 & 20.70 & 18.01 & 9.9 & 122.7 \\
\hline GDP growth rate (\%) & 3.32 & 3.33 & 3.44 & -13.13 & 14.47 \\
\hline Capital formation growth rate (\%) & 4.24 & 4.43 & 10.09 & -44.32 & 51.16 \\
\hline \multicolumn{6}{|l|}{ PCA factors } \\
\hline Insitutional environment & 0.00 & -0.19 & 1.00 & -1.68 & 1.98 \\
\hline Corporate transparency & 0.00 & -0.15 & 1.00 & -2.45 & 2.24 \\
\hline Financial market development & 0.00 & 0.12 & 1.00 & -2.70 & 2.74 \\
\hline Market concentration & 0.00 & -0.06 & 1.00 & -2.09 & 5.72 \\
\hline Infrastructure & 0.00 & 0.09 & 1.00 & -1.79 & 1.79 \\
\hline Tax benefit of debt & 0.00 & 0.00 & 1.00 & -2.03 & 3.61 \\
\hline Bankruptcy costs & 0.00 & -0.38 & 1.00 & -0.85 & 4.47 \\
\hline
\end{tabular}

The table provides summary statistics of country-level variables in our sample of 40 countries over 1995-2010. In total, there are 590 country-year observations. Original variables are those extracted from various sources that measure market imperfections and benefits of capital structure adjustments, and microeconomic conditions. Five PCA factors, institutional environment, corporate transparency, financial market development, market concentration, and infrastructure, aggregate original variables that measure market imperfections using principal component analysis (PCA). The other two PCA factors, tax benefits of debt and bankruptcy costs, aggregate original variables that measure benefits of capital structure adjustments. For detailed variable definition and data source of original variables, please see Appendix A. For details about PCA factors, please see Section 2.1.2.

com bubble burst, and nosedived in 2008 and further into the negative zone in 2009 because of the subprime financial crisis in the U.S and the Eurozone debt crisis. Capital formation growth tracks the GDP growth while the VIX reflecting uncertainty in prospects rises in downturns and declines in upturns. Based on our arguments about the effects of these factors on capital structure adjustment costs, their intertemporal variations would predict time-varying SOAs.

Table S2 in the online Supplemental Material reports the average values of the five market imperfection factors in our sample countries. A positive value is above-average. Overall, developed economies exhibit less market imperfections than developing economies. New Zealand is the only economy with five positive factors; most other developed economies, such as the U.S., Japan, and Norway have four or three positive factors. Developing economies like China and India, in contrast, have only two or fewer positive factors; Brazil and Russia have no positive factors. 
Market Imperfections

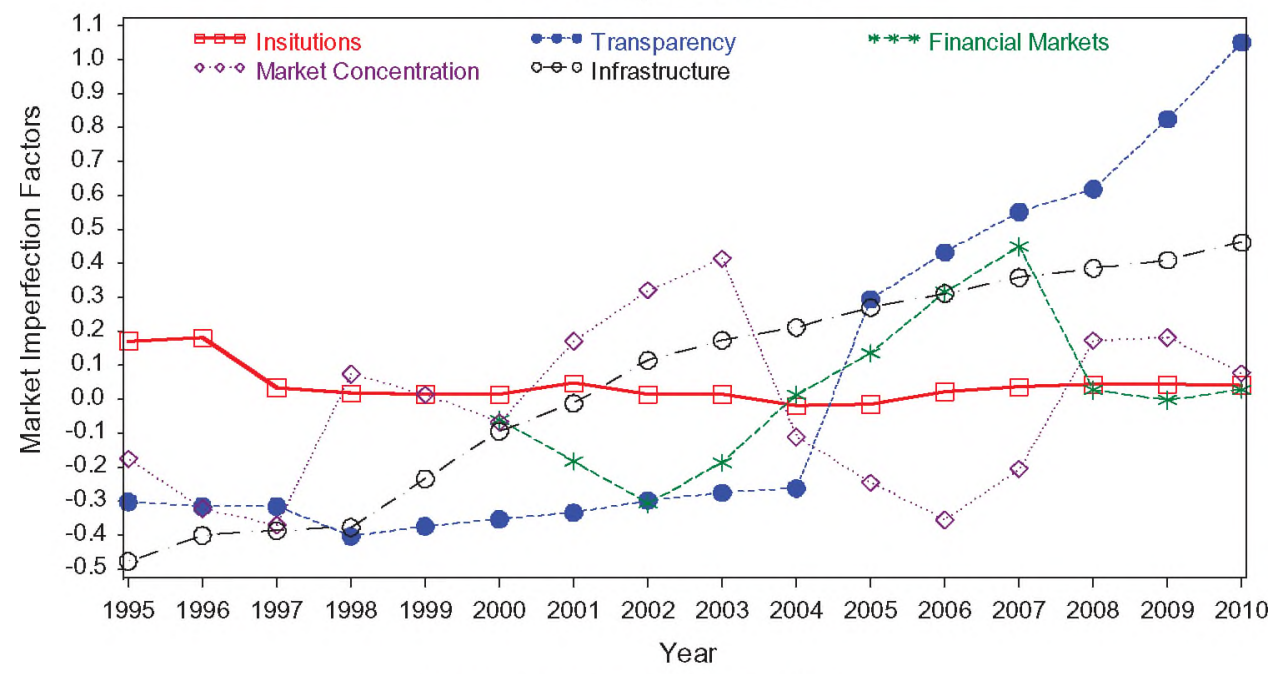

Macroeconomic Conditions

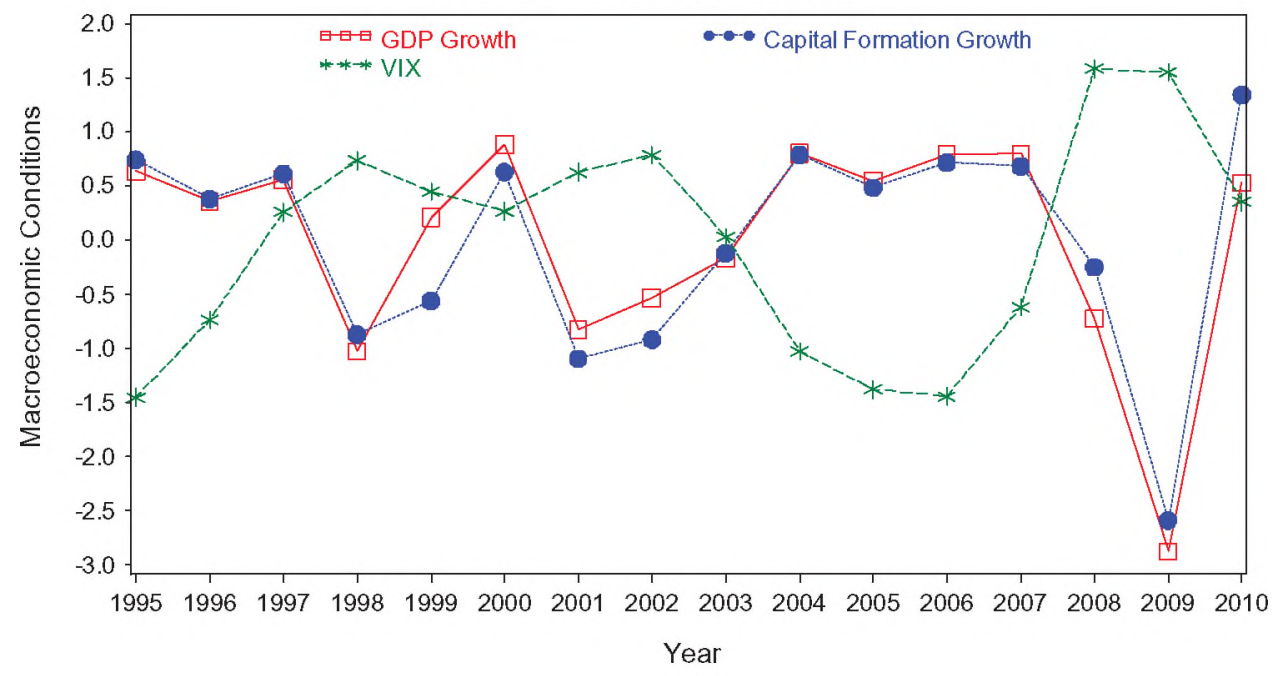

Figure 1. Market imperfections and macroeconomic conditions over time. This figure displays the variations over time of five market imperfection factors, institutional environment, corporate transparency, financial market development, market concentration and infrastructure (above), as well as three macroeconomic variables, GDP growth rate, capital formation growth rate, and VIX. Depicted are the average values across all the countries included in our sample for each year during our sample period.

\section{Capital Structure Adjustment Model}

In a multinational setting, the canonical capital structure adjustment model becomes

$$
L_{i j t}-L_{i j, t-1}=\lambda_{i t}\left(L_{i j t}^{*}-L_{i j, t-1}\right)+\varepsilon_{i j t},
$$

where $i$ and $j$ are, respectively, a country-specific and a firm-specific index, and $t$ is a fiscal year. $L_{i j, t}$ and $L_{i j, t-1}$ are the actual leverage ratio at the end of the current and the previous year, respectively, and $L_{i j t}^{*}$ represents the target leverage. Hence $L_{i j t}^{*}-L_{i j, t-1}$ is the starting deviation from the target leverage ratio, and $L_{i j, t}-L_{i j, t-1}$ is the leverage adjustment. $\lambda_{i t}$ is the speed of adjustment in country $i$ and year $t$. Note that $\lambda$ can 
take the subscript $i$ or $t$ alone instead of $i t$ to capture only cross-country variation or time variation in SOA. For expositional convenience we keep (1) as it is for now. $\varepsilon_{i j t}$ is the noise.

The target leverage, $L_{i j t}^{*}$, is conventionally expressed as a function of firm and industry characteristics (e.g., Flannery and Rangan 2006; Huang and Ritter 2009; Lemmon, Roberts, and Zender 2008),

$$
L_{i j t}^{*}=\boldsymbol{\beta}_{i t} \boldsymbol{X}_{i j, t-1},
$$

where $\boldsymbol{X}_{i j, \mathbf{t}-1}$ represents a vector of firm and industry characteristics that are predetermined at time $t-1$, including a fixed firm effect to capture unobserved firm heterogeneity, as discussed earlier. Country dummies and year dummies are also included to control for the effect of market imperfections and macroeconomic conditions on the optimal capital structure.

Substituting (2) into Eq. (1) and rearranging yields our baseline specification:

$$
L_{i j t}=\lambda_{i t} \boldsymbol{\beta}_{i t} \boldsymbol{X}_{i j, t-1}+\left(1-\lambda_{i t}\right) L_{i j, t-1}+\varepsilon_{i j t} .
$$

\section{Bootstrapping-Based Estimation}

Out of the established estimators for the dynamic panel model (3), the Blundell and Bond (1998) system GMM method, which Öztekin and Flannery (2012) use, produces consistent estimates (Flannery and Hankins 2013). The method, however, relies on the use of lagged and first-differenced variables as instruments in panel data, and hence does not fit our need of examining both cross-sectional and time variations in SOA. In contrast, the OLS can be used to estimate the SOA of a cross section of firms, in a year or a country-year, but it does not control for firm heterogeneity and generates biased estimates. A rescue comes from Iliev and Welch (2010) that suggest that the bias is removed by deducting from the raw SOA estimate an estimate in the bootstrapped placebo samples that suffers from a similar bias. ${ }^{7}$ Meanwhile, the effect of mechanical mean reversion, which inflicts all the established estimators, is also eliminated by the "control estimate" strategy because both the raw estimate and placebo estimates are exposed to similar mechanical mean reversion bias. ${ }^{8}$

We adopt this bootstrapping strategy to estimate the net SOA in countries, years, and country-years using OLS. Specifically, we estimate the SOA in our real data, which reflects the combined effect of the manager's deliberate capital structure adjustments, if any, the OLS estimator's bias, and mechanical mean reversion of leverage ratio. Then, we follow the Mukherjee and Wang (2013) null data generating process to create "placebo" samples where managerial interventions are absent, and obtain SOA estimates. These estimates reflect merely the estimator's bias and the mechanical mean reversion of leverage ratio. Hence, the difference between the real estimate and the placebo estimates tells the speed of adjustment due to deliberate leverage adjustments. For each regression, we bootstrap 1,000 placebo samples and their estimates constitute the null distribution of SOA, enabling statistical inferences. Details of the bootstrapping procedure are in the online Supplemental Material Section B.1. We also demonstrate and discuss the performance of the bootstrapping-based estimator Supplemental Material Section B.2.

\section{Market Imperfections, Macroeconomic Conditions, and SOA}

This section presents the estimated SOA, across countries, in each year, and in country-years, to exhibit their wide variations across countries and over time. Then, multiple regressions show the SOA is dependent on the market imperfections in those countries and macroeconomic conditions over time. Particularly, the procyclicality of SOA is potentially explainable by intertemporal fluctuations in adjustment costs.

First, Table 2 reports the distribution of estimated SOA in 590 country-years for both book and market debt-to-capital ratio based on model (3). For book leverage, the "Raw" estimates in the real country-year 
Table 2. Speed of adjustment in country-years.

\begin{tabular}{lrrrrrrr}
\hline & \multicolumn{3}{c}{ Book leverage } & & \multicolumn{3}{c}{ Market leverage } \\
\cline { 2 - 3 } & Raw & Placebo & Raw - Placebo & & Raw & Placebo & Raw - Placebo \\
\hline Mean & 0.168 & 0.050 & 0.118 & & 0.170 & 0.054 & 0.115 \\
Std. Dev. & 0.119 & 0.021 & 0.122 & & 0.151 & 0.021 & 0.153 \\
Minimum & -0.176 & -0.197 & -0.243 & & -0.811 & -0.158 & -0.879 \\
lst percentile & -0.085 & -0.041 & -0.174 & & -0.177 & -0.008 & -0.238 \\
Median & 0.157 & 0.049 & 0.107 & & 0.162 & 0.052 & 0.112 \\
99th percentile & 0.545 & 0.093 & 0.486 & & 0.528 & 0.109 & 0.499 \\
Maximum & 0.700 & 0.106 & 0.652 & & 0.824 & 0.163 & 0.776
\end{tabular}

This table displays the distribution of estimated speed of adjustment (SOA) in 590 country years that have at least 25 firms. The leverage is measured by the book and market debt-to-capital ratios. For each country year, the SOA is estimated using the bootstrapping-based OLS, i.e., the SOA for all firms is estimated in the real data ("Raw") as well as in 1000 bootstrapped placebo samples ("Placebo"), and the differences between the raw estimates and the corresponding average placebo estimates ("Raw - Placebo") of each country year are taken as the SOA estimates.

subsamples range from -0.176 to 0.700 , and average 0.168 , with a standard deviation of 0.119 . The average "Placebo" estimate in the 1000 bootstrapped samples exhibits a fair extent of variation across country-years, ranging from -0.197 to 0.106 , and the mean is 0.050 . After stripping off the estimation biases, the net SOA ("Raw - Placebo") averages 0.118 , in a range from -0.243 to 0.652 . Thus we observe a wide variation in country-year SOA. The SOA estimates for market leverage are very similar except that they are more volatile due to the additional volatility brought in by stock price changes.

\section{Cross-Country Variations in the Speed of Adjustment}

We verify that capital structure adjustments differ across countries by estimating the SOA in each country using the following variant of model (3):

$$
L_{i j t}=\lambda_{i} \boldsymbol{\beta}_{\boldsymbol{i}} \mathbf{X}_{j t}+\left(1-\lambda_{i}\right) L_{i j t}+\varepsilon_{i j t},
$$

where $\lambda_{i}$ is the SOA for country $i$ over its full sample period. Table 3 provides our estimates, for both book and market leverage, with their summary statistics at the bottom. Two observations are notable. First, the placebo estimates of SOA average 0.049 and 0.050 for the two leverage measures, respectively, and they are significantly positive in each country (the unreported standard errors are tiny.) After deducting the placebo SOAs, our estimates are generally lower than their counterparts reported in Öztekin and Flannery (2012). Second, the net SOA varies widely across countries. Use the book leverage as an example. At one end, the SOA is 0.235 in Norway, corresponding to a half-life of 2.6 years for leverage deviation. New Zealand, with the least market imperfections, records the second fast SOA of 0.210. At the other end, Japanese companies, on average, essentially do not readjust their capital structures, showing an SOA of -0.01 . Thus, it appears that the cross-sectional differences in market imperfections are inadequate to explain variations in capital structure adjustments. Macroeconomic conditions, which we will examine in the next session, then emerge as a potential reason.

\section{Time Fluctuations of the Speed of Adjustment}

Then we check if firms' speed of adjustment is time-contingent. Using our bootstrapping-based strategy, we estimate the yearly SOAs in three ways. The "Pooled" approach estimates the following model in each year: 
Table 3. Estimated speeds of adjustment in individual countries.

\begin{tabular}{|c|c|c|c|c|c|c|}
\hline \multirow[b]{2}{*}{ Country } & \multicolumn{3}{|c|}{ Book leverage } & \multicolumn{3}{|c|}{ Market leverage } \\
\hline & Raw & Placebo & Raw - Placebo & Raw & Placebo & Raw - Placebo \\
\hline Argentina & 0.231 & 0.052 & $0.179 * * *$ & 0.243 & 0.056 & $0.187 * * *$ \\
\hline Australia & 0.250 & 0.046 & $0.204 * * *$ & 0.231 & 0.046 & $0.185 * * *$ \\
\hline Austria & 0.125 & 0.052 & $0.073 * * *$ & 0.110 & 0.060 & $0.050 * *$ \\
\hline Belgium & 0.121 & 0.053 & $0.069 * * *$ & 0.184 & 0.062 & $0.123 * * *$ \\
\hline Brazil & 0.122 & 0.054 & $0.069 * * *$ & 0.181 & 0.058 & $0.123 * * *$ \\
\hline Canada & 0.184 & 0.049 & $0.135 * * *$ & 0.182 & 0.050 & $0.132 * * *$ \\
\hline Chile & 0.191 & 0.047 & $0.144 * * *$ & 0.225 & 0.057 & $0.168 * * *$ \\
\hline China & 0.108 & 0.059 & $0.049 * * *$ & 0.144 & 0.067 & $0.077 * *$ \\
\hline Denmark & 0.121 & 0.054 & $0.067 * * *$ & 0.123 & 0.058 & $0.065 * *$ \\
\hline Finland & 0.131 & 0.058 & $0.074 * * *$ & 0.125 & 0.064 & $0.061 * *$ \\
\hline France & 0.134 & 0.054 & $0.080 * * *$ & 0.131 & 0.055 & $0.076 * * *$ \\
\hline Germany & 0.130 & 0.050 & $0.079 * * *$ & 0.111 & 0.050 & $0.061 * * *$ \\
\hline Greece & 0.217 & 0.058 & $0.158^{* * *}$ & 0.151 & 0.051 & 0.099 \\
\hline Hong Kong & 0.207 & 0.051 & $0.157 * * *$ & 0.214 & 0.055 & $0.159 * * *$ \\
\hline India & 0.125 & 0.059 & $0.066 * * *$ & 0.138 & 0.067 & $0.071 * * *$ \\
\hline Indonesia & 0.186 & 0.049 & $0.137 * * *$ & 0.220 & 0.059 & $0.161 * * *$ \\
\hline Ireland & 0.138 & 0.056 & $0.083 * *$ & 0.160 & 0.062 & $0.098 *$ \\
\hline |srae| & 0.148 & 0.051 & $0.097 *$ & 0.211 & 0.069 & $0.142 *$ \\
\hline Italy & 0.115 & 0.057 & $0.058 * * *$ & 0.121 & 0.068 & 0.053 \\
\hline Japan & 0.042 & 0.052 & -0.010 & 0.050 & 0.058 & $-0.008 * * *$ \\
\hline Korea & 0.138 & 0.059 & $0.079 * * *$ & 0.157 & 0.071 & 0.086 *** \\
\hline Mexico & 0.208 & 0.053 & $0.154 * * *$ & 0.233 & 0.051 & $0.182 * * *$ \\
\hline Malaysia & 0.109 & 0.048 & $0.061 * * *$ & 0.108 & 0.041 & $0.067 * * *$ \\
\hline Netherlands & 0.212 & 0.048 & $0.164 * * *$ & 0.186 & 0.044 & $0.142 * * *$ \\
\hline New Zealand & 0.262 & 0.052 & $0.210 * *$ & 0.267 & 0.059 & $0.208 * * *$ \\
\hline Norway & 0.287 & 0.052 & $0.235 * * *$ & 0.264 & 0.061 & $0.203 * * *$ \\
\hline Pakistan & 0.212 & 0.055 & $0.157 * * *$ & 0.212 & 0.063 & $0.148 * * *$ \\
\hline Philippines & 0.160 & 0.055 & $0.106^{* * *}$ & 0.192 & 0.056 & $0.136 * * *$ \\
\hline Poland & 0.260 & 0.053 & $0.206 * * *$ & 0.248 & 0.053 & $0.195 * * *$ \\
\hline Portugal & 0.154 & 0.058 & $0.097 * * *$ & 0.127 & 0.058 & $0.069 * *$ \\
\hline Russia & 0.180 & 0.045 & $0.134 * * *$ & 0.228 & 0.065 & $0.163 * *$ \\
\hline Singapore & 0.143 & 0.048 & $0.094 * * *$ & 0.134 & 0.044 & $0.089 * * *$ \\
\hline South Africa & 0.256 & 0.049 & $0.207 * * *$ & 0.218 & 0.049 & $0.169 * * *$ \\
\hline Spain & 0.177 & 0.046 & $0.131 * * *$ & 0.153 & 0.052 & $0.101 * * *$ \\
\hline Sweden & 0.194 & 0.052 & $0.141 * * *$ & 0.145 & 0.054 & $0.091 * * *$ \\
\hline Switzerland & 0.153 & 0.056 & $0.097 * * *$ & 0.176 & 0.061 & $0.116 * * *$ \\
\hline Thailand & 0.109 & 0.051 & $0.058 * * *$ & 0.119 & 0.054 & $0.065 * * *$ \\
\hline Turkey & 0.227 & 0.050 & $0.178^{* * *}$ & 0.159 & 0.038 & $0.121 *$ \\
\hline UK & 0.190 & 0.044 & $0.146^{* * *}$ & 0.196 & 0.043 & $0.153 * * *$ \\
\hline USA & 0.154 & 0.043 & $0.111 * * *$ & 0.142 & 0.044 & $0.097 * * *$ \\
\hline Average & 0.170 & 0.052 & 0.118 & 0.173 & 0.056 & 0.117 \\
\hline Std Dev. & 0.053 & 0.004 & 0.055 & 0.050 & 0.008 & 0.051 \\
\hline Min & 0.042 & 0.043 & -0.010 & 0.050 & 0.038 & -0.008 \\
\hline Max & 0.287 & 0.059 & 0.235 & 0.267 & 0.071 & 0.208 \\
\hline
\end{tabular}

The table presents the estimated capital structure speed of adjustment (SOA) in each country during its sample period for leverage measured by both the book debt-to-capital ratio and market debt-to-capital ratio. The estimation is conducted with the bootstrapping-based Fama-MacBeth method: The SOA is estimated using OLS for each country-year in the real data ("Raw") as well as in 1000 bootstrapped placebo samples ("Placebo"), and the difference between the Raw estimate and the average Placebo estimate is taken as the country-year SOA estimate, and then the country-year estimates are averaged over time for each country to get the country SOA estimate. *, **, and *** marks the SOA is significantly different from zero at the $10 \%, 5 \%$, and $1 \%$ levels, respectively, based on the Newey-West standard error. The bottom section provides the distribution characteristics of the country SOA, and the Pearson correlation coefficient between the book leverage SOA and market leverage SOA. 


$$
L_{i j t}=\lambda_{t} \boldsymbol{\beta}_{t} \boldsymbol{X}_{i j t}+\left(1-\lambda_{t}\right) L_{i j, t-1}+\varepsilon_{i j t}
$$

where $\lambda_{t}$ is the average SOA of all firms in year $t$. In other words, we categorize the sample into 16 year subsamples and estimate the SOA in each cross-section pooling firms from all countries. The "Separate" approach estimates the speed of adjustment for each country-year using model (3) and then averages it across all countries. Number of firms varies substantially across country-year subsamples, lower than 50 for a few years in about a dozen countries, but greater than 4,000 in years 1995-2002 in the U.S. To account for the heterogeneous precision of SOA estimates, in the third way, "Separate Weighted", we also calculate the weighted average yearly SOA using number of firms in a countryyear as the weight.

Table 4 reports the three estimates of net SOA, in the "Pooled", "Separate", and "Separate Weighted" columns, in each year during our sample period 1995-2010, for both the book and market leverage. The "Separate" estimates are greater than the "Pooled" ones, and the "Sepa. Weighted" averages are of similar magnitude as the "Pooled", indicating countries with more sample firms adjust faster. There are discernible pro-cyclical fluctuations in the SOA over time, rising in the booms and sinking in the aftermath of the Asian financial crisis that broke out in the second half of 1997, and during the last two world-wide recessions, centered around 2002 and 2008, respectively. The SOAs hit the bottom in 2008, regardless of leverage measure or estimation method. The worst recession since the Great Depression has pushed the market SOA down to the negative zone. The procyclicality is better illustrated in Figure 2, where Plots A and B show the SOA estimates over time for book and market leverage separately. Three troughs are reached in 1998, around 2002, and in 2008, well matching the movement of average GDP growth rate as shown in Figure 1. This finding unequivocally speaks for the influence of macroeconomic conditions on firms' capital structure adjustments.

Another intriguing observation is that the SOA is moving upwards over time, with the high getting higher before the 2008 financial crisis hit the world economy. The dashed lines in Plots A and B show this trend. This is consistent with adjustment costs getting lower when information environment improves as corporate transparency and telecommunication infrastructure advance over time.

Thus far, we find the speed of adjustment not only exhibits large variations across countries as documented in Öztekin and Flannery (2012), but also substantial intertemporal fluctuations. The intertemporal patterns of SOA beg for further investigations from the chronological angle.

\section{Procyclical Capital Structure Adjustments}

In a view to further exposing the procyclicality of capital structure adjustments, we classify the 590 country-years into a "Good Times" half and a "Bad Times" half using the median GDP growth rate, and compare SOA as well as issuance/repurchase activities by firms across the two subsamples. A few articles, e.g., Korajczyk and Levy (2003) and Dittmar and Dittmar (2008), document that firms access capital markets more often during booms than during recessions. Even though not all capital market activities aim at rebalancing capital structure, the SOA should be positively correlated with the frequency of such activities.

We average the country-year SOA across the 295 country-years in each subsample, and present them in Table 5. For book leverage, in good times, the average SOA is 0.140 , which means it takes 4.6 years to eliminate half of a leverage deviation. In contrast, it is 0.096 in bad times, corresponding to a half-life of 6.9 years, which is 2.3 years, or 50 percent longer. The difference is statistically and economically significant. The results are nearly identical based on market leverage. Thus, good times feature significantly faster capital structure adjustments.

Then we check if firms engage in more capital market activities in good times. Following Leary and Roberts (2005), an issuance or repurchase is defined as having occurred in a given year if the net change in equity or debt is greater than $5 \%$ of the book value of assets. An exception is made for equity repurchases, which use a $1.25 \%$ cutoff to avoid missing most smaller-sized repurchase programs in place. In the bottom 


\section{A. SOA Over Time - Book Leverage}

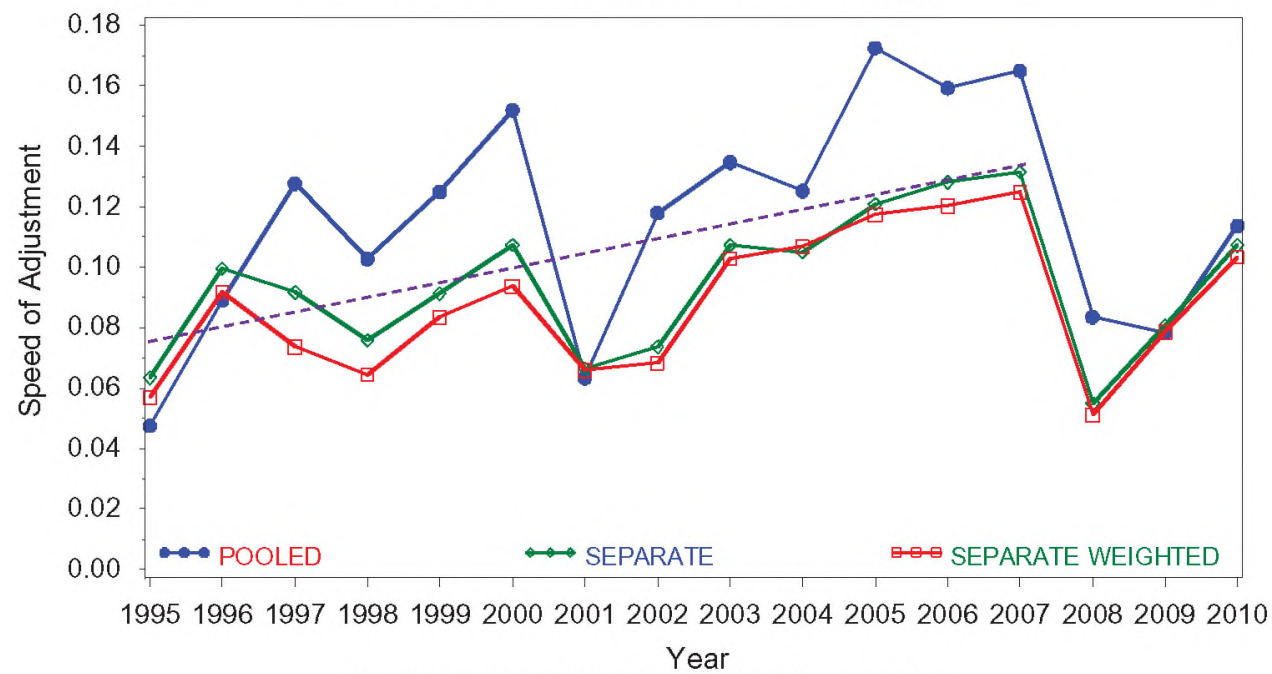

B. SOA Over Time - Market Leverage

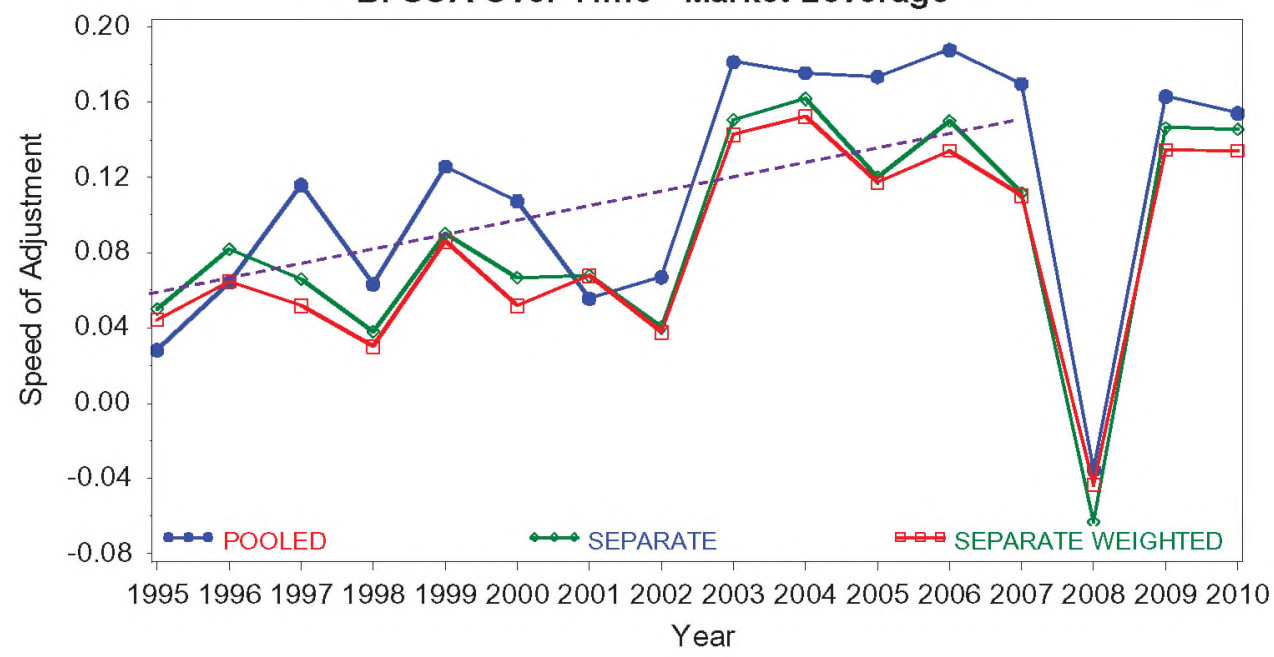

Figure 2. Capital structure speed of adjustment over time. This figure displays the variations over time of the estimated speed of adjustment (SOA) for book (Plot A) and market leverage (Plot B). The SOAs are estimated in three ways: POOLED - the SOA in a certain year is estimated using all the firm-year observations for that year, across all countries; SEPARATE - the SOA in a certain year is the average SOA across all the countries in that year; SEPARATE WEIGHTED - the SOA is the weighted average SOA across all countries in a year, using the number of firms as the weight for the SOA estimate of a country. The dashed lines roughly show the upward trend in SOA over time.

section of Table 5, we see significant discrepancies in the frequency of capital market transactions between the "Good times" subsample and its "Bad times" counterpart. In good times, 53.4\% of firms access the capital market, compared to $44.1 \%$ in bad times. The difference is mainly attributable to that in debt issuance: $30 \%$ of firms issue debt in good times vs. less than $20 \%$ in bad times. Good times also witness more active equity issuance activities. The significantly higher frequency of capital market activities in good times is consistent with the greater SOA in good times. 
Table 4. Estimated speed of adjustment for each year 1995-2010.

\begin{tabular}{|c|c|c|c|c|c|c|}
\hline \multirow[b]{2}{*}{ Year } & \multicolumn{3}{|c|}{ Book leverage } & \multicolumn{3}{|c|}{ Market leverage } \\
\hline & Pooled & Separate & Sepa. Weighted & Pooled & Separate & Sepa. Weighted \\
\hline 1995 & 0.057 & 0.048 & 0.063 & 0.044 & 0.028 & 0.050 \\
\hline 1996 & 0.092 & 0.089 & 0.100 & 0.065 & 0.064 & 0.082 \\
\hline 1997 & 0.074 & 0.128 & 0.092 & 0.052 & 0.116 & 0.066 \\
\hline 1998 & 0.064 & 0.103 & 0.076 & 0.030 & 0.063 & 0.038 \\
\hline 1999 & 0.083 & 0.125 & 0.091 & 0.086 & 0.126 & 0.090 \\
\hline 2000 & 0.094 & 0.152 & 0.107 & 0.052 & 0.107 & 0.067 \\
\hline 2001 & 0.066 & 0.063 & 0.066 & 0.068 & 0.056 & 0.068 \\
\hline 2002 & 0.068 & 0.118 & 0.074 & 0.038 & 0.067 & 0.040 \\
\hline 2003 & 0.103 & 0.135 & 0.107 & 0.143 & 0.181 & 0.151 \\
\hline 2004 & 0.107 & 0.125 & 0.105 & 0.152 & 0.176 & 0.162 \\
\hline 2005 & 0.117 & 0.173 & 0.121 & 0.117 & 0.173 & 0.120 \\
\hline 2006 & 0.120 & 0.159 & 0.128 & 0.134 & 0.188 & 0.150 \\
\hline 2007 & 0.125 & 0.165 & 0.132 & 0.110 & 0.170 & 0.112 \\
\hline 2008 & 0.051 & 0.084 & 0.055 & -0.043 & -0.035 & -0.063 \\
\hline 2009 & 0.079 & 0.078 & 0.081 & 0.135 & 0.163 & 0.146 \\
\hline 2010 & 0.103 & 0.114 & 0.107 & 0.134 & 0.154 & 0.146 \\
\hline Average & 0.088 & 0.116 & 0.094 & 0.082 & 0.112 & 0.089 \\
\hline Std. Dev. & 0.023 & 0.037 & 0.023 & 0.053 & 0.066 & 0.059 \\
\hline Min & 0.051 & 0.048 & 0.055 & -0.043 & -0.035 & -0.063 \\
\hline Max & 0.125 & 0.173 & 0.132 & 0.152 & 0.188 & 0.162 \\
\hline \multicolumn{7}{|c|}{$\begin{array}{l}\text { The table presents the estimated capital structure speed of adjustment (SOA) in each year over the } 1995-2010 \text {. The } \\
\text { leverage is measured by the book and market debt-to-capital ratios. The SOAs reported are obtained in three ways. In the } \\
\text { "Pooled" way, SOA is estimated using all the firm-year observations in a year. In the "Separate" way, SOA is estimated } \\
\text { for each country-year and then averaged across all the countries in the year. The "Sepa. Weighted" way is similar to the } \\
\text { "Separate" way, except that the yearly SOA is the weighted average of all country-year estimates using the number of } \\
\text { firms as the weight. In each way, the SOA estimation is conducted using the bootstrapping-based strategy, i.e., estimating } \\
\text { the SOAs using OLS in the real data and also in the } 500 \text { bootstrapped placebo samples, and taking the difference } \\
\text { between the real sample estimate and the average placebo sample estimate as the SOA. }\end{array}$} \\
\hline
\end{tabular}

\section{Determinants of Capital Structure SOA}

In multivariate analysis, we run a regression of the country-year capital structure SOA on market imperfections and macroeconomic conditions:

$$
\lambda_{i t}=f\left(\text { Market frictions }_{i t}, \text { macroeconomic conditions }_{i t}, \text { Controls }_{i t}\right)+\varepsilon_{i t},
$$

where $\lambda_{i t}$ is the SOA for firms in country $i$ and year $t$. Market imperfections are measured by the five factors defined earlier, including institutional environment, corporate transparency, financial market development, market concentration, and infrastructure. GDP growth rate serves as the aggregate proxy of macroeconomic conditions.

There are two groups of control variables: tax advantage of debt and bankruptcy costs gauging adjustment benefits are included in all the specifications, and average firm characteristics are brought in some specifications. Some firm characteristics may have a direct effect on the SOA, for example, larger firms might have better access to the capital markets and enjoy higher SOA (Jalivand and Harris 1984). The ease of capital market access potentially depends on the relative size of a firm in an economy. Thus we find the firm assets relative to the GDP for each firm and use the median value across all firms in the country-year as a control variable. Similarly, all other firm characteristics used to instrument leverage target in model (2) are adopted as controls. In addition, we employ the median 
Table 5. Procyclicality of capital structure adjustments.

\begin{tabular}{|c|c|c|c|c|}
\hline & Low & High & & \\
\hline & GDP Growth & GDP Growth & High - Low & $\operatorname{Pr}>$ It $\mid$ \\
\hline \multicolumn{5}{|l|}{ Book leverage } \\
\hline SOA & 0.096 & 0.140 & 0.044 & \multirow[t]{2}{*}{$<0.001$} \\
\hline Half life of deviation (years) & 6.9 & 4.6 & -2.3 & \\
\hline \multicolumn{5}{|l|}{ Market leverage } \\
\hline SOA & 0.091 & 0.140 & 0.049 & \multirow[t]{2}{*}{$<0.001$} \\
\hline Half life of deviation (years) & 7.3 & 4.6 & -2.7 & \\
\hline \multicolumn{5}{|l|}{ Issuance/Repurchase activities } \\
\hline All & 0.441 & 0.534 & 0.093 & $<0.001$ \\
\hline Debt & 0.369 & 0.464 & 0.095 & $<0.001$ \\
\hline Debt issuance & 0.198 & 0.300 & 0.102 & $<0.001$ \\
\hline Debt retirement & 0.170 & 0.164 & -0.006 & 0.001 \\
\hline Equity & 0.144 & 0.157 & 0.013 & $<0.001$ \\
\hline Equity issuance & 0.128 & 0.143 & 0.015 & $<0.001$ \\
\hline Equity repurchase & 0.016 & 0.013 & -0.003 & 0.001 \\
\hline \multicolumn{5}{|c|}{$\begin{array}{l}\text { This table presents the comparison between the low and high GDP growth subsamples of country years in terms of the } \\
\text { speed of adjustment (SOA), and issuance/repurchase activities. A country-year is classified into the high growth half if } \\
\text { its GDP growth rate is greater than the median rate, or otherwise the low growth half. SOAs reported are the average } \\
\text { across all estimated country-year SOAs in a subsample. The bottom section presents the fractions of firms that access the } \\
\text { financial market and how these activities break down between debt and equity and between issuances and repurchases. } \\
\text { An issuance (repurchase) is defined as having occurred in a given year if the net change in equity or debt is greater than } \\
5 \% \text { (lower than }-5 \% \text { ) of the book value of assets. For equity repurchases, the criterion is }-1.25 \% \text { of the assets. }\end{array}$} \\
\hline
\end{tabular}

value of a dividend payer indicator because Fama and French (2002) document dividend payers exhibit a slower SOA than those that do not pay dividends.

Three specifications of the model are employed: in the baseline specification, market imperfections, adjustment benefits and GDP growth rate are used as explanatory variables; in specification 2, firm characteristics are included; in the third, two more macroeconomic variables, capital formation growth and VIX index, are brought in to examine the channels through which macroeconomic conditions affect capital structure dynamics.

We use two estimators. First, in order to account for heterogeneity in SOA estimation precision across country-years, we estimate model (6) using the weighted least square (WLS) method, giving observations in "larger" country-years greater weights. Both the standard deviation of the raw SOA estimate and the variance of placebo SOA across 1000 repetitions exhibit variations that are negatively related to the "size" of country-year, i.e., number of firms in the country-year. The WLS estimator effectively treats each firmyear observation, rather than each country-year observation, equally, and hence mitigates potential heteroscedasticity. Specifically, we use the reciprocal of bootstrapped variance of placebo SOA as the weight. ${ }^{9}$ Also, we conduct fixed effects (FE) estimation to control for unobserved country heterogeneity because the five market imperfection factors may not exhaustively capture country characteristics that affect capital structure adjustments. ${ }^{10}$

\section{Estimation Results}

The left-hand side of Table 6 reports WLS results for book leverage SOA. Column (1) presents our baseline regression estimates. The dependent variable, estimated SOA, is scaled up by a factor of 100 . The R-squared of the estimation is 0.261 . Out of the five proxies of (the lack) of market imperfections, institutional environment, corporate transparency, market concentration and infrastructure have positive 
Table 6. Determinants of capital structure speed of adjustment (SOA).

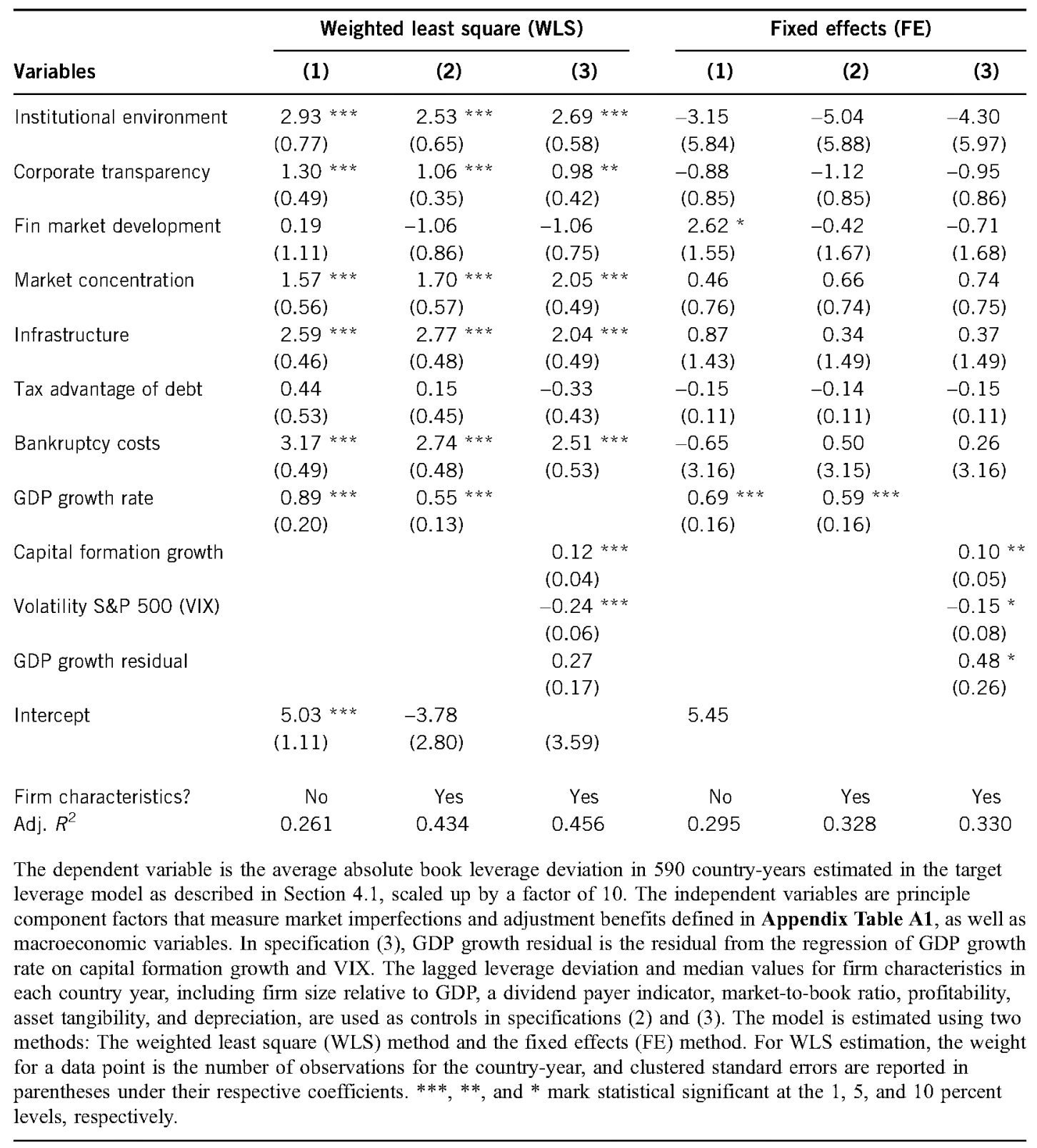

coefficients that are statistically significant at the one percent level. This is consistent with fewer market frictions being associated with lower adjustment costs and hence faster capital structure adjustments. The positive coefficient of the market concentration factor suggests that the economy of scale effect dominates the market power effect. This comes as no surprise because the both the equity underwriting market and credit market in most of our sample countries are quite competitive (see Table 1) and a certain degree of concentration might be good news as market players benefit from better information synergy. Financial market development has a positive coefficient, too, but it is not statistically significant. Tax advantage of debt and bankruptcy costs both have positive coefficients, and the latter is statistically significant, 
indicating higher bankruptcy costs are associated with faster adjustments. This result is due to the adjustment benefit considerations. Stronger threat of bankruptcy makes the firm value curve of a leveraged company more concave; holding adjustment costs constant, an adjustment would enhance the firm value by more, and it hence is more likely to take place. These results stay unchanged in specification (2) with firm characteristics controlled for.

The procyclicality of SOA is manifest in the positive coefficient of GDP growth rate, which is statistically significant at the one percent level. A one-percentage-point increase in GDP growth rate causes the SOA to accelerate by 0.89 percentage point. The strength of the effect is better illustrated by two comparisons. First, compare the expansions and recessions in the U.S. The GDP growth rate typically increases from a negative number at the bottom of a recession to 4-5 percent, and this implies an increase in SOA by about 4 percentage points, which is substantial. Then, compare China and Japan. During our sample period, Japan's annual GDP growth rate is close to zero while China has been growing at a rate of around 10 percent, and this gap would cause a staggering difference in SOA of 9 percentage points. The particularly low SOA in Japan in spite of its above-average (lack of) market imperfections, is likely attributable to its stagnant economic activities. This result remains the same in specification (2).

The right-hand side of Table 6 reports the FE estimates. A notable difference from WLS results is that essentially all the five market imperfection factors receive coefficients that are not significantly different from zero after firm characteristics are considered. ${ }^{11}$ In contrast, GDP growth rate receives coefficients that are similar in magnitude and statistical significance as the WLS estimates. This indicates that these market imperfection factors mainly determine cross-country differences in SOA, while macroeconomic conditions play a more important role in shaping within-country variations in capital structure adjustments.

\section{Channels of Macroeconomic Effect}

Questions then ensue: What are the channels through which macroeconomic conditions affect capital structure adjustments? To test our "free-ride restructuring" and "uncertainty alleviation" hypotheses, we orthogonalize GDP growth rate against the growth rate of capital formation in an economy, and the CBOE volatility index, VIX. ${ }^{12}$ In doing so, we literally decompose the GDP growth into a factor that is closely associated with firms' aggregate capital expenditures in an economy, a factor that tracks uncertainty in the financial markets, and the residual. Then we use capital formation growth, VIX, and residual GDP growth as macroeconomic variables in the model. Estimation results are reported in columns (3) of Table 6.

In both WLS and FE estimation, capital formation growth loads positively and VIX loads negatively, consistent with both the "free-ride restructuring" hypothesis and the "uncertainty alleviation" hypothesis. The residual GDP growth does not load in the WLS estimation; it still loads in the FE estimation but with a much lower statistical significance. These results indicate that much of the GDP effect is accounted for by the free-ride restructuring and uncertainty alleviation effects.

\section{Robustness Check}

Regression results in Table 6 are based on book debt-to-capital ratio, but those based on the market book-to-capital ratio are similar. We also use liabilities-to-asset ratios in place of debt-to-capital ratios, and all the SOA patterns across countries and over time as well as multiple regression results do not change qualitatively.

We have constructed the five market imperfection factors based on 13 country characteristics. Although our selection and classification of country characteristics have theoretical, empirical or at least anecdotal support, it is not free of arbitrariness. To assuage the concern, we have experimented different ways to construct the factors. For instance, we bring in the market efficiency in addition to market size to measure the financial market development (Levine 2002). Specifically, the "Financial market development" factor is the first principal component of equity market size, credit market size, stock market trading volume and overhead costs of the banking sector. These modifications do not 
alter our results qualitatively. In addition, we conduct the principal component analysis on the five factors to create two aggregate market imperfection factors to summarize all the market imperfections proxies and eliminate potential multicollinearity, ${ }^{13}$ and they both load with expected signs and high statistical significance in the multiple regressions.

Our bootstrapping-based estimation requires a reasonable data generating process for the placebo samples that detach deliberate managerial interventions in capital structure. While we believe our bootstrapping procedure outlined in Appendix B meets the requirements, the definition of debt-tocapital ratios makes it impossible for a zero-debt firm to become leveraged in the simulation. This could give rise to too many zero-debt observations in the placebo samples and lower placebo SOAs. In an alternative procedure, we treat zero-debt firm years with special care: the random match is picked from a subset of other zero-debt firms with similar sizes instead of from the big pool of all firms, and the original firm receives the next-year level of debt amount instead of the percent debt change from the match firm. Whether zero-debt firms are different from others is debatable, but the special treatment helps generate a pattern of leverage change for zero-debt firms that is even more similar to what we observe in the real world. In our robustness check, this alternative bootstrapping procedure does not change our findings.

Another concern about our baseline bootstrapping approach is that random draws are from the whole sample disregarding the country characteristics. As more firm-year observations are from developed, more transparent economies such as the U.S., the indiscriminate random drawing could misrepresent the true random movement for a firm in countries with higher imperfections, and as a result the inferred deliberate adjustment would be downwardly biased. ${ }^{14}$ To address this concern, we draw the equity and debt changes from within the country. The estimated SOAs are not discernibly different from those reported in Table 2.

\section{Conclusion}

Adjustment costs are generally viewed as an explanation of the wide variation in capital structure. They impede firms from timely rebalancing their capital structures, leading to slow speeds of adjustment and large deviations from the optimal leverage. We investigate the capital structure adjustments in a cross-country setting, allowing for intertemporal variations in adjustments. Using country-level market imperfections and macroeconomic conditions to proxy for systematic adjustment costs confers an advantage that they are less likely to be endogenous to firms' capital structure decisions.

Our investigation involves the use of a bootstrapping-based strategy to estimate the capital structure SOA. This strategy addresses the mechanical mean reversion propensity of leverage ratios, and when combined with the OLS estimator, is flexible for estimation needs in country-year subsamples. We find substantial variations in capital structure SOA across countries as well as over time. These variations are to a great extent explainable by market imperfections and macroeconomic conditions. A good legal and institutional environment with effective corruption control and stronger investor protection, better corporate transparency and information dissemination facilitate capital structure adjustments and lead to smaller deviations from target leverage. The concentration of capital market intermediaries is associated with faster adjustments, consistent with the economy of scale bringing down their service costs. Intertemporally, capital structure adjustments exhibit strong procyclicality. Economic growth is positively correlated with SOA and frequency of firms' issuance/repurchase activities, and negatively correlated with leverage deviation. A one-percentage-point increase in GDP growth rate would enhance SOA by 0.9 percentage point. Further examinations reveal that the procyclicality is consistent with both the "free-ride restructuring" hypothesis and the "uncertainty alleviation" hypothesis. The former holds that vibrant capital expenditures during good times incur frequent visits to the capital markets that leverage restructuring free rides. The latter holds that economic booms alleviate uncertainty about the economic prospects and reduce market frictions. 
Insofar as market imperfections and macroeconomic conditions determine transaction costs of debt and equity issuance/repurchase activities, our cross-country and intertemporal findings provide unequivocal evidence that adjustment costs play a significant role in firms' capital structure decisions. This is consistent with the dynamic tradeoff theory of capital structure, and shed light on the sources of wide variations in capital structure we observe.

\section{Notes}

1. See, among others, Hovakimian, Opler, and Titman (2001), Fama and French (2002), Welch (2004), Leary and Roberts (2005), Flannery and Rangan (2006), Lemmon, Roberts, and Zender (2008), and Huang and Ritter (2009).

2. For instance, the literature documents that SOA depends on firm size (Jalivand and Harris 1984), default risk (Elsas and Florysiak 2011), cash flows (Faulkender et al. 2012), and availability of credit lines (Lockhart 2014).

3. Firm characteristics like firm size, default risk, cash flows, and availability of credit lines may be influenced by the firm's capital structure decisions or determined jointly with capital structure decisions by some common factors. In contrast, some of the country characteristics we use, such as legal tradition and telecommunication infrastructure are clearly exogenous to firms' capital structure decisions; it is not likely that macroeconomic conditions and other country-level variables like the adoption of International Accounting Standards, equity underwriter concentration and bank concentration are endogenous, either. Discussion about country-level proxies is in Section 2.1 .

4. We start our sample period from 1995 for two considerations. First, the WDI starts providing data in 1995. Second, reasonable economic and market data are not available for some important economies, e.g., Brazil and Russia, in the first half of the 1990s, due to various reasons.

5. Prior research (e.g., De Jong, Kabir, and Nguyen 2008; Demirgüç-Kunt and Maksimovic 1999; Fan, Titman, and Twite 2012; Öztekin and Flannery 2012; Öztekin 2015) document that country-specific factors like the legal origin influence the level and/or adjustment speed of capital structure. We are unable, however, to simply borrow their variables because the need to consider time variation of market imperfections restricts the availability of certain data.

6. Given the huge impact of the U.S. economy on the rest of the world, we assume the perceived uncertainty in other economics track that in the U.S. market and hence the VIX index measures the uncertainty across all economies.

7. This bias is mainly the omitted variable bias in favor of not finding mean reversion as Iliev and Welch (2010), among others, point out. A potential problem of this bootstrapping-based estimator is that the explanatory variables may be correlated with the stochastic error term in the real data, but not in the bootstrapped placebo data. We thank an anonymous referee for raising it up. However, this concern is mitigated by the bootstrapping results based on different estimators as discussed in Section 2.3 .

8. Mechanical mean reversion stems from the nonlinearity of debt ratio. Chen and Zhao (2007) showed that, in terms of contribution to leverage changes, debt financing has a greater impact on lower levered firms, while equity financing and retained earnings have a greater impact on higher levered firms. This creates mean reversion regardless of financing strategies.

9. Alternatively we use the reciprocal of the estimated variance of raw SOA as the weight and results are not different qualitatively.

10. We thank an anonymous referee for the suggestion. The FE method enables us to examine the relationship between within-country variations of SOA and its determinants.

11. Type III tests for fixed effects show that fixed effects do exist and significantly affect the coefficients of all the market imperfections variables other than corporate transparency.

12. The connection between capital formation and financing activities was established in economic literature such as Kuznets and Jenks (1961) and Malkiel (1979). VIX is often used as a measure of financial market uncertainty (e.g., Bloom 2014; Volkert, 2015).

13. Among the five factors, Infrastructure has relatively high correlations with Institutional environment, Corporate transparency and Financial market development ( $\rho$ between 0.3 and 0.5 ), and Financial market development is highly correlated with Institutional environment $(\rho=0.6)$. Between all other pairs of factors, the correlation coefficients are low, between -0.1 and 0.1 .

14. We thank an anonymous referee for pointing out this possibility. 


\section{References}

Bachmann, R., and G. Moscarini. 2011. Business cycles and endogenous uncertainty. Working paper, Yale University.

Beck, T., and A. Demirgüç-Kunt. 2009. Financial institutions and markets across countries and over time: Data and analysis. World Bank Policy Research Working Paper No. 4943.

Bloom, N. 2009. The impact of uncertainty shocks. Econometrica 77:623-85. doi:10.3982/ECTA6248.

Bloom, N. 2014. Fluctuations in uncertainty. Joumal of Economic Perspectives 28:153-76. doi:10.1257/jep.28.2.153.

Blundell, R., and S. Bond. 1998. Initial conditions and moment restrictions in dynamic panel data models. Journal of Econometrics 87:115-43. doi:10.1016/S0304-4076(98)00009-8.

Booth, L., V. Aivazian, A. Demirgüç-Kunt, and V. Maksimovic. 2001. Capital structures in developing countries. Journal of Finance 56:87-130. doi:10.1111/0022-1082.00320.

Chang, X., and S. Dasgupta. 2009. Target behavior and financing: How conclusive is the evidence? Journal of Finance $64: 1767-$ 96. doi: 10.1111/j.1540-6261.2009.01479.x.

Chen, L., and X. Zhao. 2007. Mechanical mean reversion of leverage ratios. Economic Letters 95:223-29. doi:10.1016/j. econlet.2006.10.008.

Choe, H., R. Masulis, and V. Nanda. 1993. Common stock offerings across the business cycle. Journal of Empirical Finance 1:3-31. doi:10.1016/0927-5398(93)90003-A.

Cook, D., and T. Tang. 2010. Macroeconomic conditions and capital structure adjustment speed. Journal of Corporate Finance 16:73-87. doi:10.1016/j.jcorpfin.2009.02.003.

De Jong, A., R. Kabir, and T. Nguyen. 2008. Capital structure around the world: The roles of firm- and country-specific determinants. Journal of Banking and Finance 31:1954-69. doi:10.1016/j.jbankfin.2007.12.034.

Demirgüç-Kunt, A., and R. Levine. 2001. Financial Structure and Economic Growth: A Cross-Country Comparison of Banks, Markets and Development. Cambdridge, MA: MIT.

DeGennaro, R. 2005. Market imperfections. Journal of Financial Transformation 14:107-17.

Demirgüç-Kunt, A., and V. Maksimovic. 1999. Institutions, financial markets and firm debt maturity. Journal of Financial Economics 54:295-336. doi:10.1016/S0304-405X(99)00039-2.

Dittmar, A., and R. Dittmar. 2008. The timing of financing decisions: An examination of the correlation in financing waves. Journal of Financial Economics 90:59-83. doi:10.1016/j.jineco.2007.11.007.

Driffield, N., and S. Pal. Evolution of capital structure in East Asia: Corporate inertia or endeavours? Working paper, Brunel University, 2007.

Drobetz, W., P. Pensa, and G. Wanzenried. Firm characteristics and dynamic capital structure adjustment. Working paper, University of Hamburg, 2006.

Drobetz, W., and G. Wanzenried. 2006. What determines the speed of adjustment to the target capital structure? Applied Financial Economics 16:941-58. doi:10.1080/09603100500426358.

Dudley, E. 2012. Capital structure and large investment projects. Journal of Corporate Finance 18:1168-92. doi:10.1016/j. jcorpfin. 2012.07.007.

Eisfeldt, A. 2004. Endogenous liquidity in asset markets. Journal of Finance 59:1-29. doi:10.1111/j.1540-6261.2004.00625.x.

Elsas, R., and D. Florysiak. 2011. Heterogeneity in the speed of adjustment toward target leverage. International Review of Finance 11:181-211. doi:10.1111/irfi.2011.11.issue-2.

Fama, E., and K. French. 2002. Testing trade-off and pecking order predictions about dividends and debt. Review of Financial Studies 15:1-33. doi:10.1093/rfs/15.1.1.

Fan, J., S. Titman, and G. Twite. 2012. An international comparison of capital structures and debt maturity choices. Journal of Financial and Quantitative Analysis 47:23-56. doi:10.1017/S0022109011000597.

Faulkender, M., M. Flannery, K. Hankins, and J. Smith. 2012. Cash flows and leverage adjustments. Journal of Finance Economics 103:632-46. doi:10.1016/j.jfineco.2011.10.013.

Fischer, E., R. Heinkel, and J. Zechner. 1989. Dynamic capital structure choice: Theory and Tests. Journal of Finance 44:19-40. doi:10.1111/j.1540-6261.1989.tb02402.x.

Flannery, M., and K. Hankins. 2013. Estimating dynamic panel models in corporate finance. Journal of Corporate Finance 19:1-19. doi:10.1016/j.jcorpfin.2012.09.004.

Flannery, M., and K. Rangan. 2006. Partial adjustment toward target capital structures. Journal of Financial Economics $79: 469$ 506. doi:10.1016/j.jfineco.2005.03.004.

Hackbarth, D., J. Miao, and E. Morellec. 2006. Capital structure, credit risk, and macroeconomic conditions. Journal of Financial Economics 82:519-50. doi:10.1016/j.jfineco.2005.10.003.

Hovakimian, A., T. Opler, and S. Titman. 2001. The debt-equity choice. Journal of Financial and Quantitative Analysis 36:1-24. doi: $10.2307 / 2676195$.

Huang, R., and J. Ritter. 2009. Testing theories of capital structure and estimating the speed of adjustment. Journal of Financial and Qualitative Analysis 44:237-71. doi:10.1017/S0022109009090152.

Iliev, P., and I. Welch. Reconciling estimates of the speed of adjustment of leverage ratios. Working paper, UCLA, 2010.

Jalivand, A., and R. Harris. 1984. Corporate behavior in adjusting to capital structure and dividend targets: An econometric study. Journal of Finance 39:127-45. doi:10.1111/j.1540-6261.1984.tb03864.x.

Jappelli, T., and M. Pagano. 1989. Consumption and capital market imperfections: An international comparison. American Economic Review 79:1088-105.

Korajczyk, R., and A. Levy. 2003. Capital structure choice: Macroeconomic conditions and financial constraints. Journal of Financial Economics 68:75-109. doi:10.1016/S0304-405X(02)00249-0.

Kuznets, S., and E. Jenks. 1961. Capital in the American economy: Its formation and financing. Princeton: Princeton University Press. 
La Porta, R., F. Lopes-De-Silanes, A. Shleifer, and R. Vishny. 1997. Legal determinants of external finance. Journal of Finance 52:1131-50. doi:10.1111/j.1540-6261.1997.tb02727.x.

La Porta, R., F. Lopes-De-Silanes, A. Shleifer, and R. Vishny. 1998. Law and finance. Journal of Political Economy 106:111355. doi:10.1086/250042.

Leary, M., and M. Roberts. 2005. Do firms rebalance their capital structures? Journal of Finance 60:2575 619. doi:10.1111/ j.1540-6261.2005.00811.x.

Lemmon, M., M. Roberts, and J. Zender. 2008. Back to the beginning: Persistence and the cross-section of corporate capital structure. Journal of Finance 63:1575-608. doi:10.1111/j.1540-6261.2008.01369.x.

Levine, R. 2002. Bank-based or market-based financial systems: Which is better? Journal of Financial Intermediation 11:398428. doi:10.1006/jin.2002.0341.

Lockhart, G. B. 2014. Credit lines and leverage adjustments. Journal of Corporate Finance 25:274-88. doi:10.1016/j. jcorpfin.2013.12.011.

Malkiel, B. G. 1979. The capital formation problem in the United States. Journal of Finance 34:291-306. doi:10.1111/j.15406261.1979.tb02092.x.

Mukherjee, W., and W. Wang. 2013. Capital structure deviation and speed of adjustment. The Financial Review 48:597-615. doi: 10.1111 fire. 12017.

Myers, S. 1984. The Capital Structure Puzzle. Journal of Finance 39:575-92. doi:10.2307/2327916.

Oztekin, O. 2015. Capital structure decisions around the world: Which factors are reliably important? Journal of Financial and Quantitative Analysis 50 (3):301-23.

Öztekin, Ö., and M. Flannery. 2012. Institutional determinants of capital structure adjustment speeds. Journal of Financial Economics 103: 88-112. doi:10.1016/j.jfineco.2011.08.014.

Rajan, R., and L. Zingales. 1995. What do we know about capital structure? Some evidence from international data. Journal of Finance 50:1421-60. doi:10.1111/j.1540-6261.1995.tb05184.x.

Strebulaev, I. 2007. Do tests of capital structure theory mean what they say? Journal of Finance 62:1747-87. doi:10.1111/j.15406261.2007.01256.x.

Völkert, C. 2015. The distribution of uncertainty: Evidence from the VIX options market. Journal of Futures Markets 35:597624. doi:10.1002/fut.v35.7.

Welch, I. 2004. Capital structure and stock returns. Journal of Political Economy 112:106-32. doi:10.1086/379933. 


\section{Appendix A}

\section{Table A1. Country characteristics.}

Common law
Market-based financial
system
Corruption perception index
Creditor legal rights

Shareholder right protection

Accounting standards

Depth of credit information

Size of equity market

Size of credit market

Equity underwriter concentration

Bank concentration

Telephone lines

Internet users

corporate income tax rate Interest tax deductibility

Time to resolve insolvency

Cost of debt recovery

GDP growth rate

Capital formation growth rate
A dummy variable, $=1$ if a country's legal origin is the English common law, and $=0 \quad$ (7) otherwise.

A dummy variable, $=1$ if a country's financial system is market-based, or $=0$ if it is (8) bank-based.

The extent to which corruption is perceived to exist among public officials. Ranges from 0 (worst corruption) to 10 (minimum corruption).

Strength of legal rights index, ranging from 0 (weakest) to 10 (strongest). Measures the degree to which collateral and bankruptcy laws protect the rights of borrowers and lenders and thus facilitate lending.

Strength of investor protection index, ranging from 0 (weakest) to 10 (strongest). It measures the strength of minority shareholder protections against directors' misuse of corporate assets for personal gain.

Measured as the percentage of firms that adopts the International Accounting Standards (IAS)/International Financial Reporting Standards (IFRS), i.e., the Compustat Global data item ACCTSTD is equal to 'DA', 'DI', 'DT'.

Measures rules affecting the scope, accessibility, and quality of credit information available through either public or private credit registries. It ranges from 0 (least information) to 6 (most information).

Measured as the logarithm of the stock market capitalization (MV) divided by GDP, i.e., $\ln (\mathrm{MV} / \mathrm{GDP})$.

Measured as the logarithm of the total private credits divided by GDP.

The Hirfindahl index of investment banks' market shares in the common stock primary market.

Assets of three largest banks as a share of assets of all commercial banks.

Number of fixed telephone lines per 100 people.

Number of internet users per 100 people.

The highest statutory corporate income tax rate.

An indicator describing the extent to which interest payments enjoy tax advantage relative to dividend payments. It is equal to 0 for the classical tax system in which dividend payments are double taxed and interest payments are tax deductible; equal to 1 for the partial dividend relief or dividend imputation tax system in which dividend payments enjoy partial tax credits; and equal to 2 for the full dividend relief or dividend imputation tax system.

Number of years for creditors to recover their credit, measures as the period of time from the company's default until the payment of some or all of the money owed to the bank.

The cost of the credit recovery proceedings as a percentage of the value of the debtor's estate.

Nominal GDP percentage growth rate.

Annual percentage growth rate of gross capital formation, consisting of outlays on addition to the fixed assets of the economy plus net changes in the level of inventories.

The table provides the definitions and data sources of original country characteristics in our sample. The definitions of characteristics are shown below. Data sources are: (1) Computstat Global Vantage; (2) World Bank: World Development Indicator Database; (3)World Bank: Doing Business Database; (4) Transparency International; (5) Thomson-Reuters SDC Platinum; (6) OECD and KPMG Corporate Income Tax Survey; (7) La Porta et al. (1997, 1998)); (8) Demirgúç-Kunt and Levine (2001); (9) Beck and Demirgüç-Kunt (2009); (10) Fan, Titman, and Twite (2012). 